\title{
SPECIFIC FEATURES OF THE CONSUMER CREDIT CONTRACT ENFORCEMENT Livia MOCANU
}

\author{
„Valahia” University, Târgovişte, Romania \\ mocanulivia@yahoo.com
}

\begin{abstract}
Consumers' demands for purchasing goods and services, which are more and more complex and different, have been and are insured, in the absence of the necessary or sufficient amounts of money, by means of credits granted for consumption; the field in question is generically named "consumer credit. This financial-legal mechanism which is widely spread and useful contains the consumer credit contract as key element, which has some specific features for private law, both in terms of its constitution and enforcement. Given its relatively recent existence within the Romanian legal system, the present work aims to carry out an analysis of the main rules governing the enforcement of the consumer credit contract, in the context of the national and European legislation.
\end{abstract}

Keywords: consumer credit, withdrawal right, credit reimbursement, assets restitution, assignment of rights

\section{Introduction}

Having a specific mission and nature in terms of the relations between professionals and consumers, the consumer credit has experienced a considerable evolution in the last years. New credit instruments have emerged on the market, which continue to be more and more used and create new challenges for both those granting credits and those applying for them. An answer to this phenomenon has been the adoption of Directive No. 2008/48/EC of the European Parliament and Council, on $23^{\text {rd }}$ April 2008, regarding credit consumer contracts [1] and having the declared objective to create a harmonized community framework within some fundamental fields. The new regulation has instituted a set of similar crediting conditions for credit consumers, in any of the EU member states, both in terms of the formation and the enforcement of the consumer credit. As an effect of the Directive and with the aim to transpose it on a national scale, the G.E.O. No. 50/2010 on credit consumer contracts [2] was adopted, being a normative act which radically modifies the legal regime enforceable to the constitution and effects of the consumer credit contract.

The current study captures the legal regime thus instituted in the field of enforcing the consumer credit contract, where two situations can be distinguished: the lack of enforcement or the faulty one of a selling contract by the seller and the lack of enforcement or the partial one of the duties belonging to the consumer within the credit contract.

2. The lack of enforcement of the selling/enterprise contract

Articles 64 and 65 of the G.E.O. No. $50 / 2010$ deal with the case in which the assets or services which constituted the object of a united credit contract or of an unsuitable enforcement of such contract 
have not been provided, either completely or just in part, but also with the accountability of the seller and creditor for this hypothesis. Thus, article 64 reveals the alliance with the provisions of Law No. $449 / 2003$ on the selling of products and the guarantees associated to them [3], under the governance of which shall take place the legal relations between the consumer and seller, any time the consumer did not receive the assets or services expected or they are unsuitable.

This is the legal solution which the lawmaker clearly provides for the situations in which a united credit contract has been concluded, the definition of which can be found at article 7 point 3 of law, using the provisions of article 3 letter $n$ ) of Directive 2008/48/EC of the European Parliament and Council from $23^{\text {rd }}$ April 2008. For the purposes of law, the united credit contract is a credit contract meeting altogether the following conditions:

a) the credit in question is exclusively used to finance a contract whose object is the provision of assets or of a certain service;

b) the credit contract and that for the purchase of assets or services constitute a commercial unit, from an objective perspective.

The commercial unit resulting from the credit contract and the contract for the purchase of assets or services has its own definition, at article 7 point 16 of the G.E.O. No. 50/2010, according to which it is involved a commercial unit in one of the following situations:

a) the service provider or supplier finances himself the credit for the consumer;

b) the credit is financed by a third party, while the creditor uses the services of the provider or supplier for concluding the credit contract or for preparing it;

c) the assets involved or the provision of a certain service are clearly specified in the contract credit (the credit is granted for covering those needs of the consumer mentioned in the contract).

These crediting proposals are particularly encountered in the commercial areas of the seller or the service provider and raise the issue of the interdependence between the two contracts - the credit contract and the selling contract - when it comes to flaws related to conformity. For these situations, the lawmaker has chosen to maintain both contractual relations (selling/providing services, crediting), the consumer being offered the legal remedies of the legal guarantee of conformity [4]. This time, the consumer does not have a legal term to change his mind neither when it comes to the selling/service providing contract, nor to the united credit contract, so that he cannot ask for the credit to be abolished by motivating that the asset/service is not provided by the seller/contractor or it is not according to the specifications in the selling contract. The reference to the provisions of Law No. 449/2003 is justified, as this normative act imperatively institutes the legal guarantee of conformity, which can be doubled by a contractual guarantee, which is by all means more advantageous for the consumer than the legal one. The emergence of the flaws related to the lack of conformity renders available concrete legal remedies to the consumer. The complaints made by the consumer according to Law No. 449/2003 does not trigger however the suspension of the effects of the united credit contract, as the consumer is still bound to pay the instalments and the relative due interests. Nonetheless, on the basis of the interdependence existing between the two contracts in question, if the consumer's claims regarding the conformity of the product are not met, then he can resort to legal ways against the creditor/bank, in order to obtain the termination of the united credit contract.

We are speaking here about a hierarchy of the legal remedies rendered available to the consumer by the lawmaker, also pointed out by the provisions of article 65 of the G.E.O. No. 50/2010, which reasserts the provisions 
of article 15 paragraph (2) of the Directive 2008/48/EC of the European Parliament and the Council, from $23^{\text {rd }}$ April 2008. According to the legal text, when the assets or services which are the object of a united credit contract are not provided or are partially provided or are not according to the provision contract, the consumer has the right to take the legal remedies against the creditor, if he did not manage to get an answer from the provider to his claims rightfully stated according to the legislation or the contract for the provision of assets or services [article 65 paragraph (1)]. Consequently, the consumer must first of all resort to the seller, on the basis of Law No. $449 / 2003$, to which he shall demand to remove the lack of conformity affecting the product; if his request receives no answer, then he will address the creditor, to which he shall demand the termination of the credit contract.

Although the European lawmaker establishes that the EU member states have the duty to determine the extent and the conditions in which the right to compensations can be applied, if assets are not provided or are not appropriate, the Romanian lawmaker forgets to deal with this aspect. We are underlining here only the importance which would have had the establishment of the moment in which the consumer has the opportunity to exert a legal action for claims against creditors.

At the second paragraph of article 65 it can be noticed that the Romanian lawmaker has committed an error by comparison with the similar text from Directive No. 2008/48/EC. In brief, we are speaking about article 15 paragraph (3) of the Directive mentioned above, according to which: "The present article does not affect the national norms according to which the creditor is jointly accountable for any claim which the consumer may have against the provider, if the provider's assets or services have been financed by a contract credit. It is instituted a joint accountability of the creditor and seller for any claim which the consumer may have against the seller". These provisions take the form of article 65 paragraph (2) of the G.E.O. No. 50/2010, according to which: "The creditor is jointly accountable with the seller for any claim which the consumer might have against the seller". In reality, the joint accountability expressed by the text of the Romanian Ordinance is not encountered among the provisions of the Directive, which does not speak of the joint accountability of the seller and creditor within the united credit contract for the lack of conformity of products. The Directive allows for the enforcement of the national norms already existing in cases such as those regarding joint accountability for illicit deeds caused by several authors and creating prejudices. Certainly, according to the provisions of article 65 of the G.E.O. No. 50/2010, the united credit contract shall not exist after it has been acknowledged that the contract for the purchasing of assets and services, which it finances, has not been accordingly enforced; consequently, the failure of the legal remedies regarding the according enforcement triggers as an effect of the interdependence of the two contracts the possibility for the consumer to obtain the extinguishment of duties emerging from the credit contract - legacy, against the creditor. Thus, against the background of the connectivity between the two contracts and the association of the interests of the two professionals from the credit and commerce field, with the view to gain profit, the lawmaker has created a quite efficient system to protect the costumer, according to Directive 2008/48/EC. This aspect underlines the progress registered in the field as compared to the previous provisions, included at article 14 of Law No. 289/2004 which, although had the deducted premise of the same relation of interdependence between the loan and selling contract, this interdependence was nonetheless not assumed completely [5].

3. The lack of enforcement of the loan contract 


\subsection{Anticipated reimbursement}

As legal doctrine [6] also underlines, one of the main pillars of the legal protection instituted in the field of consumer credit is the configuration of the technical-legal details for exerting the right of the anticipated reimbursement of credits. Taking into account the provisions of article 16 paragraph (1) Thesis 1 of Directive 2008/48/EC, according to which the "Consumer must have the right to become free at any moment, in total or in part, of his duties contracted with a credit contract", it can be asserted that the right of anticipated reimbursement of the credit occupies a special place in the context of the normative act. In agreement with the text of Directive, article 66 of the G.E.O. No. 50/1990 acknowledges the right of the consumer to reimburse in advance a credit. According to law, the costumer is entitled in this case to a reduction of the total cost of the credit, reduction consisting in the interest and the costs corresponding to the period between the date of anticipated reimbursement and the date regulated for the termination of the credit contract. At the same time, the right of the consumer to reimburse the credit in advance cannot be conditioned by the payment of a certain minimum amount of money or by a certain number of instalments [article 66 paragraph (2)]. As it results from law, the decision to reimburse a credit in advance can be taken at any time, as the creditor cannot condition the use of this right on the existence of a certain number of paid instalments or by stipulating that the anticipated reimbursement could not be partial. By proceeding to the anticipated reimbursement of the credit, the consumer obtains a reduction of its total cost, consisting in the interest and the costs corresponding to the period between the date of anticipated reimbursement and the date provided for the termination of the credit contract.

According to article 67 of the G.E.O. No. $50 / 2010$, the exertion of the right to reimburse a credit in advance has an onerous character, so that the creditor is entitled to an objective compensation. The text of the law states that the debtor "... owes an equitable and objectively justified compensation to the bank, for the potential costs directly connected to the anticipated reimbursement of the credit, on the condition that the anticipated reimbursement intervenes in a period when the interest rate corresponding to the credit is a fixed one" [article 67 paragraph (1)]. Consequently, the compensation related to the anticipated reimbursement does not apply for those cases in which the anticipated reimbursement of the credit is made during periods with a variable interest rate, when the bank/the creditor has benefitted from objective mechanisms for adjusting the interest rate, so it can no longer transfer to the responsibility of the consumer the financial losses generated by the anticipated recovery of the credit. Considering the way it is calculated, in relation to the reference indexes clearly mentioned in the contract, the variable interest protects the bank from the financial unbalances resulting from the modification of crediting conditions, while the consumer does not enjoy a similar protection. The legal condition mentioned above is also found in the text of Directive 2008/48/EC (article 16), being considered at an European level too that the variable interest is enough to cover the financial losses of the bank, which can no longer charge additional taxes for the anticipated reimbursement. Moreover, among all EU member states, there is a uniform legal ceiling for the maximum value of the compensation related to the reimbursement of the credit, also used by the Romanian lawmaker, at the second paragraph of article 67 of G.E.O. No. 50/2010. Thus, the compensation cannot exceed:

a) $1 \%$ from the value of the credit reimbursed in advance, if the period between the anticipated reimbursement and the date agreed for the termination of the credit contract is longer than one 
year;

b) $0,5 \%$ from the value of the credit reimbursed in advance, if the period between the anticipated reimbursement and the date agreed for the termination of the credit contract is no longer than one year.

Regarding the way the value of the compensation is determined, the law establishes that the creditor has the duty to inform the consumer on the calculation method ever since the period preceding the conclusion of the contract; this method has to be clear and easy to check [article 67 paragraph (3)].

At article 68 if the G.E.O. No. 50/1990 are stipulated three cases in which banks are forbidden to claim compensations for the reimbursement in advance.

a) the reimbursement has been made as a result of the enforcement of an insurance contract aiming to insure the risk of non-payment

b) the credit contract is granted in the form of an "overdraft"

c) the anticipated reimbursement intervenes in a period in which the rate of the interest corresponding to the credit is not a fixed one.

Briefly commenting on these situations, it should be pointed out that, in the first case, the anticipated reimbursement is not based on the debtor's initiative, but takes place instead as an effect of his insolvency (the risk of non-payment), in the context of a conclusion of an insurance contract regarding the risk of non-payment between the bank and an insurance society, the reimbursement being made by using the funds of the insurance society. The second situation is justified by the fact that the anticipated reimbursement of the credit is incompatible with the overdraft mechanism. Thus, while the anticipated reimbursement leads to the total or partial extinguishment of the debt by means of payment, the essence of the overdraft is that the partial or complete payments made by the consumer do not lead to the extinguishment of the debt, as they can be reused immediately as a credit title [7]. In this case, the bank cannot use the reimbursed amounts of money for the extinguishment of the debt, but can only take the commitment to keep them at the consumer's disposal, a fact which does not allow for receiving the commission for anticipated reimbursement. The last situation reasserts the requirement expressed at article 67, according to which the compensation for the anticipated reimbursement of the credit shall not be obtained if the reimbursement is made during periods with a variable interest.

The final text which defines the mechanism of anticipated reimbursement of the credit is article 69 of the G.E.O. No. 50/1990, according to which: "No compensation can overcome the amount of the interest which the consumer would have paid during the period between the anticipated reimbursement and the date agreed for the termination of the credit contract". Thus, the Romanian lawmaker abides by the provisions of article 16 paragraph (5) of the Directive 2008/48/EC, by establishing a maximum global ceiling for the value of the compensation related to anticipated reimbursement. It can be hence noticed that in the field of anticipated reimbursement two legal ceilings are used. The legal mechanism imposes first of all to apply the legal ceiling regarding the maximum value of the compensation, which is of $1 \%$ of the value reimbursed in advance for the credits longer than one year and, respectively, $0,5 \%$ of the of the value reimbursed in advance for the credits shorter than one year. After that, the procedure shall pass to the classification in the second legal ceiling, regarding the value of the interest during the interval stipulated in the contract.

The transgression of the legal duties provided for the anticipated reimbursement of the credit by the professional creditor represents a crime and is sanctioned with a civil fine (article 86).

\subsection{The assignment of rights}

The essence of the field is represented by 
articles $70-71$ of the G.E.O. No. 50/2010, which reproduce article 17 of Directive 2008/48/EC, according to which, when it comes to credit contracts concluded on the territory of the EU member states, the assignment of the creditor's rights or of the contract itself triggers the legal correspondence with the exceptions in relation to the assignee, whereas the assigned debtor shall be informed on the assignment. Article 70 regulates the legal mechanism triggering the opposability in relation to the assignee of the exceptions which could have been opposed to the assignor by the assigned debtor, with two components: the assignment of the debt and the assignment of the credit contract on its whole. Legal doctrine defines the assignment of a contract as the legal technique of substituting a contractor with a third party, that is with a person who did not take part to the constitution of the credit contract in question, the consequence being the replacement of one of the original parties (the bank creditor) with the assignee, who shall hence benefit from all the effects of a contract with the conclusion of which he has nothing to do [8]. Together with the assignment of the contract, the creditor assignee takes up contractual relations as they were reflected by the initial credit contract, while the assigned debtor remains the same.

By means of the regulations above, the consumer (assigned debtor) is protected, so that after the assignment the right to invoke all his contractual rights at his disposal against a third person (creditor assignee) does not suffer from any limitation or damage [9]. By derogation from common law (articles 1315-1316 of Civil Code), both when a debt or a contract are assigned, it is enough for the assigned debtor (consumer) to be informed on the assignment, not being necessary his agreement.

Article 71 of the G.E.O. No. 50/2010 regulates the information of the consumer regarding assignment. This time, the information insures the opposability of assignment, so that the assignor is bound to notify the consumer on this. The notification must be done within 10 days from the conclusion of the assignment contract, by means of a registered letter, with confirmation of receipt. According to law, the notification must comprise the identity of the creditor assignee, which shall cash from the consumer the amounts of money for the credit reimbursement, but also the name and address of the registered office and the working point of the legal representative in Romania. The legal text also institutes the duty of the assignee to have a contact person in Romania, for settling eventual conflicts and for answering before public authorities. The text of the law also institutes the duty of the assignee to have a contact person in Romania for settling eventual litigations and for answering before public authorities. In this field too, the transgression of legal duties provided for the professional creditor represent a crime and are sanctioned with a civil fine (article 86).

\section{Conclusions}

The complex issue regarding the enforcement of the credit consumer contract has allowed only for a partial approach of the rules in the field instituted by the G.E.O. No. 50/1990, on the transposition of Directive 2008/48/EC in internal law. Certainly, the current regulation brings novelty elements, but the crediting relations are those which will nonetheless underline the advantages and disadvantages of the legal text.

\section{References}

[1] Published in the OJEC, No. 133/66 from $22^{\text {nd }}$ May 2008.

[2] Published in the Official Gazette No. 389 from $11^{\text {th }}$ June 2010.

[3] Published in the Official Gazette No. 812 from $18^{\text {th }}$ November 2003. The Law entered 
in force on January $1^{\text {st }} 2007$.

[4] Ana-Juanita Goicovici, Creditele pentru consum şi de investiţii imobiliare. Comentarii şi explicaţii, Bucharest, C.H.Beck Publ. House, 2014, p. 261.

[5] Emilia Mihai, Lecţii de dreptul consumului, Timişoara, Mirton Publ. House, 2007, pp. 216-219.

[6] Ana-Juanita Goicovici, quoted works, pp. 10-11.

[7] Ana-Juanita Goicovici, quoted works, p. 275.

[8] Paul Vasilescu (coord.), Cesiunea de contract, Sfera juridică Publ. House, Cluj-Napoca, 2007, pp. 44-53.

[9] Rodica Diana Apan, Protecția juridică a consumatorilor. Creditul destinat consumului și domeniile conexe, Sfera juridică Publ. House, Cluj-Napoca, 2007, p. 192. 